\title{
The effect of rolling contact fatigue properties on 316 stainless steel under laser shock peening
}

\author{
fengze Dai ${ }^{1}$, Wei Cheng ${ }^{1}$, and yueyang Zheng ${ }^{1}$
}

${ }^{1}$ Affiliation not available

August 4, 2020

\begin{abstract}
In this paper, 316 stainless steel was treated by laser shock peening (LSP) technology, and the micro-hardness, residual stress and rolling contact fatigue ( $\mathrm{RCF}$ ) performance were investigated. The result suggests that LSP can effectively improve the RCF performance of 316 stainless steel. The main factor is that LSP can induce high amplitude compressive residual stress on the surface layer. With the increase of residual compressive stress, the worn mechanism of RCF surface changes from delamination to micro-plastic deformation. It is also found that the RCF of 316 stainless steel treated by LSP was sensitive to the contact stress.
\end{abstract}

\section{Hosted file}

FFEMS------manuscript.doc available at https://authorea.com/users/348639/articles/473847the-effect-of-rolling-contact-fatigue-properties-on-316-stainless-steel-under-lasershock-peening

\section{Hosted file}

FFEMS---table.doc available at https://authorea.com/users/348639/articles/473847-the-effectof-rolling-contact-fatigue-properties-on-316-stainless-steel-under-laser-shock-peening

\section{Hosted file}

FFEMS- Figure.doc available at https://authorea.com/users/348639/articles/473847-the-effectof-rolling-contact-fatigue-properties-on-316-stainless-steel-under-laser-shock-peening 